\title{
KARAKTERISASI ENZIM PENISILIN ASILASE DARI ESCHERICIA COLI B-130.
}

\author{
Nies Suci Mulyani \\ Laboratorium Biokimia, Jurusan Kimia F MIPA Universitas Diponegoro
}

\begin{abstract}
AESTRAK
Telah dilakukan karakterisasi enzim penisilin asilase hasil isolasi dari Eschericia coli B-130. Karakterisasi meliputi $\mathrm{pH}$ optimum, temperatur optimum, tetapan Michaelis Menten $\left(\mathrm{K}_{\mathrm{m}}\right)$, kecepatan maksimum $\left(V_{m}\right)$. Aktivitas enzim penisilin asilase ditentukan dengan metode Komfeld pada $\lambda 538 \mathrm{~nm}$. hasil penelitian menunjukkan bahwa $\mathrm{pH}$ optimum $=7,5$, temperatur optimum $55^{\circ} \mathrm{C}$, tetapan Michaelis Menten $\left(K_{m}\right)=0,86 \mu \mathrm{M}$ kecepatan reaksi maksimum $\left(V_{m}\right)$ untuk pembetnukan produk 6-APA sebesar 147 $\mu \mathrm{mol} / \mathrm{mL}$ enzim
\end{abstract}

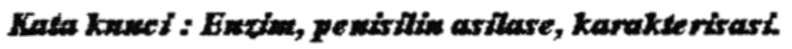

ABSTRACT

Enxym Penicyllin Acylase Caracterisation of $E$. Cof B-130

Caracteritation as the optimum $\mathrm{pH}$, the optimum temperature, the Michaelis Menten constant $\left(\mathrm{K}_{\mathrm{m}}\right)$ and the maximum rate. The activity of penicillin acylase was determined by Kormfeld method at $\lambda .538 \mathrm{~nm}$. The conclusion are the optimum $\mathrm{pH}$ was 7,5, the optimum temperature was $55^{\circ} \mathrm{C}$ : The Michaelis Menten constant was $0,86 \mathrm{mM}$ and the maximum rate of $6-\mathrm{APA}$ was $147 \mathrm{mmol} 6-\mathrm{APA} / \mathrm{mL}$ enzim.

Keyword : Enzyme, penictllin acylase, caractersation

\section{PENDAHULUAN}

Akhir-akhir ini hampir selunuh obat jadi farmasi sudah dapat dibuat di dalam negeri, tetapi sebagian besar bahan bakumya masih harus didatangkan dari har negeri. Hal imi disebabkan karena Indonesia sampai saat ini behum mampu memenuhi kebutuhan akan bahan baku obat terutama untuk antibiotika.

Penisilin merupakan salah satu jenis antibiotika yang banyak digunakan untuk pengobatan berbagai perryakit yang disebabkan oleh mikroorganisme seperti jamur, bakteri dan virus, karena kemampuan antimikrobanya cukup tinggi ${ }^{(1)}$. Penisilin termasuk antibiotik $\beta$ laktam yang terdiri dari 6-APA (sebagai inti penisilin) dan rantai samping yang terikat pada $\mathrm{C}_{6}$ dari asam 6-amino penisilanat $(6-\mathrm{APA})^{(2)}$. 


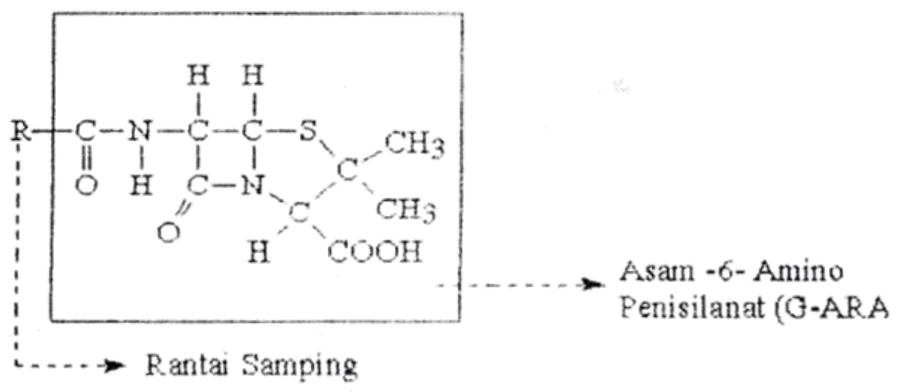

Penisilin alam yang mula-mula ditemukan oleh Fleming, diperoleh pada media biakan jamur Penicillium nototum ${ }^{(3)}$. Kekurangan dari sifat penisilin alam tidak tahan panas, asam dan basa, sering menimbulkan alergi. Serta banyakmya kuman yang kebal terhadar antibiotika, terutama yang mampu mensintesa $\beta$-laktanase $e^{(4)}$. Hal inilah yang mendorong peneliti untuk memperoleh jenis penisilin baru yang sifatnya lebih baik dari penisilin alam.

Dari penelitian yang telah dilakukan oleh Abraham dan kawan-kawan; diperoleh hasil bahwa perbedaan struktur samping dari penisilin menimbulkan sifat antibiotika yang baru. Penisilin yang diperoleh dengan cara ini disebut penisilin semisintetik ${ }^{(4)}$. Yang menjadi masalah utama dalam pembuatan penisilin semi

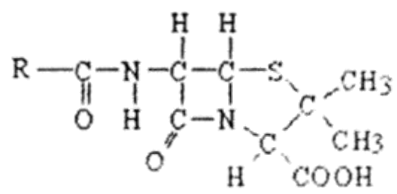

Pendsilin a silase

Reaksi sintesis penisilin dikatalisis oleh enzim yang sama, hidrolisis berlangsung pada $\mathrm{pH}$ sedikit basa $(7,5-9,0)$, sedangkan reaksi sintesis berlangsung pada $\mathrm{pH}$ sedikit asam.Keberhasilan dalam penyediaan 6-APA sintetik adalah penyediaan inti molekul penisilin yaitu asam 6-amino penisilanat (6-APA). Senyawa 6-APA ini dapat diperoleh secara hidrolisis kimiawi, enzimatik maupun fermentasi dari penisilin alam maupun secara fermentasi. Yang ba-nyak dilakukan orang adalah cara enzimatik, karena biayanya relatif lebih murah. Pada cara enzimatik, 6-APA diperoleh melalui re-aksi hidrlisis penisilin dengan bantuan enzim penisilin asilase yang dapat diperoleh dari berbagai mikroorganisme ${ }^{(5)}$.

Penisilin asilase merupakan enzim yang dapat mengkatalisis reaksi hidrolisis penisilin pada ikatan amida yang menghu-bungkan rantai samping asil dengan inti pe-nisilin menjadi 6APA dan asam karboksilat ${ }^{(2)}$

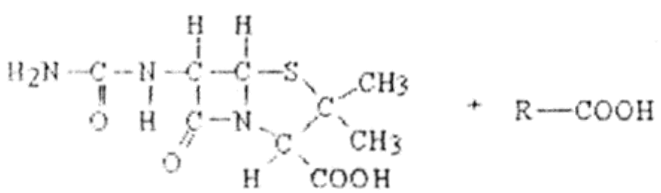

dan pembuatan penisilin semi sintetik selain ditentukan oleh kualitas dari enzim penisilin asilase juga perlu diketahui kondisi optimum yang merupakan karakter dari enzim penisilin asilase yang digunakan ${ }^{(6)}$. Karena dengan 
menggunakan enzim penisilin asilase yang mempunyai aktivitas yang tinggi dan kondisi lingkungan (temperatur, $\mathrm{pH}$ ) yang mendukung, maka produksi 6-APA sebagai inti penisilin akan meningkat demikian juga hasil penisilin semi sintetikmya.

Dalam penelitian ini akan dicoba untuk mengetahui kondisi optimum enzim penisilin asilase hasil isolasi dari Eschericia coli B-130.

\section{TUJUAN PENELITIAN}

Memperoleh kondisi optimum dan parameter kinetik enzim penisilin asilase hasil isolasi dari bakteri Eschericia coli

\section{B-130.}

\section{METODOLOGI}

Penelitian ini menggunakan enzim penisilin asilase hasil isolasi dari bakteri Eschericia coli B130 yang ditumbuhkan dalam medium Morita dan Iwata yang me-ngandung asam fenil asetat $0,2 \%$ sebagai penginduksi.

Hasil yang diperoleh kemudian di-fraksinasi dengan menggunakan ammonium sulfat secara bertingkat, dilanjutkan pemur-nian dengan kolom kromatografi DEAE-Sephacel.

Enzim yang diperoleh dari hasil pemurnian terakhir, kemudian ditentukan $\mathrm{pH}$ optimum, temperatur optimum serta parame-ter kinetik $\mathrm{V}_{\mathrm{m}}$ (kecepatan maksimum) dan $\mathrm{K}_{\mathrm{m}}$ (tetapan Michaelis Menten). Pengukuran aktivitas enzim penisilin asilase dengan cara Kornfeld, atas dasar pengukuran intensitas warna yang ditimbulkan oleh pereaksi Erlich pada panjang gelombang $538 \mathrm{~nm}$ dan kadar protein ditentukan dengan cara Lowry.

1 Unit aktivitas enzim dinyatakan sebagai ak-tivitas enzim yang dapat menghasilkan $1 \mu \mathrm{mol}$ substrat ( bensilpenisilin ) pada kondisi per-cobaan.

\section{HASIL dan PEMBAHASAN}

\section{a. Penentuan pH optimum enxim penisilin asilase.}

Penentuan $\mathrm{pH}$ optimum enzim penisilin asilase dilakukan berdasarkan pengukuran 6-APA hasil reaksi enzimatik antara enzim penisilin asilase dengan substrat benzil penisilin pada berbagai harga $\mathrm{pH}$. Harga $\mathrm{pH}$ yang menunjukkan jumlah 6-APA yang tertinggi merupakan $\mathrm{pH}$ optimum bagi kerja enzim penisilin asilase tersebut.

Pengaruh $\mathrm{pH}$ terhadap aktivitas en-zim penisilin asilase dapat dilihat dari tabel 1 dan gambar 1 berikut :

Tabel 1. Data penentuan $\mathrm{pH}$ optimum

\begin{tabular}{|c|c|}
\hline ifif & $\begin{array}{l}\text { Aktitos sposink } \\
\text { whth ne prot }\end{array}$ \\
\hline 6,5 & 5,24 \\
\hline 7,0 & 7,78 \\
\hline 7,5 & 14,55 \\
\hline 8,0 & 9,08 \\
\hline 8,5 & 6,04 \\
\hline
\end{tabular}

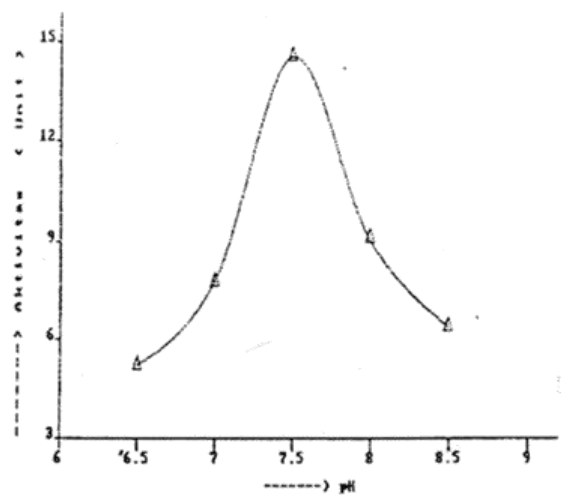

Gambar 1. Pengaruh pH terhadap aktivitas enxim penisilin asilase 
Pada pH 7,5 diperoleh aktivitas enzim penisilin asilase tertinggi, oleh karena itu $\mathrm{pH}$ tersebut merupakan $\mathrm{pH}$ optimum dari enzim penisilin asilase. Perubahan $\mathrm{pH}$ sangat mempengaruhi aktivitas enzim sebab $\mathrm{pH}$ dalam larutan, menunjukkan jumlah ion $\mathrm{H}^{+}$yang ada dalam larutan. Sehingga perubahan $\mathrm{pH}$-sangat mempengaruhi muatan listrik pada enzim maupun substrat. Pada enzim perubahan $\mathrm{pH}$ sangat mempengaruhi pusat aktif enzim yang terdiri dari asam-asam amino. Perubahan muatan listrik dapat mengakibatkan perubahan kon-formasi maupun perubahan muatan pada residu asam amino yang berfungsi sebagai pengikat substrat.

\section{b. Penentuan temperatur optimum enxim penisilin asilase.}

Laju reaksi yang dikatalisis oleh enzim seperti halmya reaksi kimia biasa yang akan meningkat dengan peningkatan suhu. Tetapi perlu diingat bahwa enzim seperti halmya semua protein yang akan mudah rusak konformasinya pada temperatur tertentu

Setiap enzim mempunyai temperatur optimum yang karakteristik, pada temperatur tersebut enzim akan memiliki aktivitas tertinggi.

Penentuan temperatur optimum enzim penisilin asilase dilakukan berdasarkan pengukuran 6-APA yang terbentuk dari hasil reaksi antara enzim penisilin asilase dengan substrat benzil penisilin pada berbagai temperatur.Harga temperatur yang menunjukkan jumlah 6-APA tertinggi merupakan temperatur optimum untuk kerja enzim tersebut.Pengaruh temperatur terhadap aktivitas enzim dapat dilihat pada tabel 2 dan gambar 2.

Tabel 2. Data penentuan temperatur optimum

\begin{tabular}{|c|c|}
\hline Temperatur & gktivitas spesifin \\
\hline 27 & 1,89 \\
\hline 37 & 2,01 \\
\hline 40 & 2,93 \\
\hline 45 & 3,42 \\
\hline 50 & 9,76 \\
\hline 55 & 14,56 \\
\hline 60 & 8,64 \\
\hline 65 & 5,72 \\
\hline
\end{tabular}

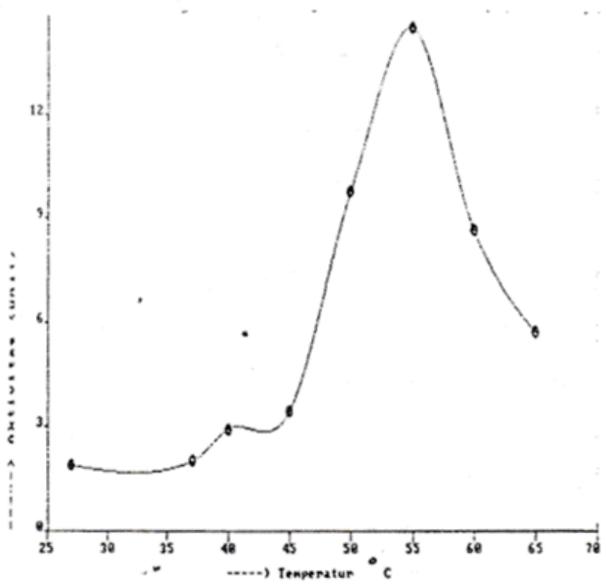

Gambar 2. Pengaruh temperatur terhadap aktivitas enzim penisilin asilase

Aktivitas enzim yang tertinggi diperoleh pada temperatur $55^{\circ} \mathrm{C}$ yang merupakan temperatur optimum untuk enzim tersebut. Pada temperatur $27^{\circ} \mathrm{C}$ sampai $55^{\circ} \mathrm{C}$ terlihat adanya kenaikan aktivitas enzim dengan naiknya temperatur, sedangkan mulai $55^{\circ} \mathrm{C}$ 
sampai $65^{\circ} \mathrm{C}$ terlilat penurunan aktivitas enzim dengan naiknya temperatur. Hal ini disebabkan kenaikan temperatur akan berpengaruh terhadap ikatan-ikatan yang lemah seperti ikatan hidrogen, sehingga akan terjadi pembukaan ikatan non kovalen pada struktur kwarterner menjadi struktur tertier. Hal tersebut akan menyebabkan perubahan konformasi enzim terutama pada residu asam amino yang berfungsi untuk mengikat substrat sehingga akan menurunkan aktivitas enzim penisilin asilase tersebut.

\section{c. Penentuan parameter kinetik enzim penisilin asilase.}

Keefektifan enzim sebagai katalis dapat diperkirakan dari harga $V_{m}$ dan $K_{m}$ nya. Harga $\mathrm{V}_{\mathrm{m}}$ (kecepatan reaksi maksi-mum). sangat tergantung dari kadar enzim pada suatu larutan. Ini merupakan batas teoritis karena hanya dapat dicapai bila substrat terdapat dalam konsentrasi yang tinggi sekali, dan tidak ada produk yang menempati tempat aktif. Jadi merupakan kecepatan reaksi bila enzim telah dijenuhi oleh substrat.

Sedangkan $\mathrm{K}_{\mathrm{m}}$ (tetapan MichaelisMenten) merupakan kecenderungan bergabungnya enzim dengan substrat untuk menghasilkan produk.

Penentuan $V_{m}$ dan $K_{m}$ enzim penisilin asilase dilakukan berdasarkan pada pengukuran aktivitas enzim penisilin asilase pada berbagai konsentrasi substrat. Pengaruh konsentrasi substrat terhadap aktivitas enzim penisilin asilase dapat dilihat pada tabel 3 dan gambar 3 .
Dari data yang diperoleh dapat dianalisis dengan persamaan Lineweaver Burk yang merupakan kebalikan dari persaman Michaelis Menten berikut :

$$
v=\frac{V_{m} \cdot[S]}{K_{m}+[S]}
$$

$\mathbf{v}$ : laju reaksi (aktivitas enzim)

$\mathrm{V}_{\mathrm{m}}$ : laju reaksi maksimum

$\mathrm{K}_{\mathrm{m}}$ : tetapan Michaelis Menten

$$
\frac{1}{\mathrm{~V}}=\frac{\mathrm{K}_{\mathrm{m}}+[\mathrm{S}]}{\mathrm{V}_{\mathrm{m}}+[\mathrm{S}]}
$$

$$
\frac{1}{V}=\left[\frac{K_{m}}{V_{m}} \times \frac{1}{[S]}\right]+\frac{1}{V_{m}}
$$

yang bila dibuat grafik $1 / v$ vs $1 /[S$ ] akan diperoleh garis hurus. Titik potong antara garis dengan absis akan diperoleh $1 \mathrm{Vm}$ sedangkan titik potong garis dengan ordinat akan diperoleh VKm

Tabel 3. Data penentuan $K_{m}$ dan $V_{m}$

\begin{tabular}{|c|c|c|c|}
\hline [S] & $\mathbf{v}$ & $\mathbf{1} /[\mathbf{S}]$ & $\mathbf{1} / \mathbf{v}$ \\
\hline 0,5 & 96,636 & 2 & 0,01035 \\
1,0 & 111,912 & 1 & 0,00894 \\
1,5 & 117,004 & 0,67 & 0,00855 \\
2,0 & 125,151 & 0,50 & 0,00799 \\
2,5 & 127,188 & 0,40 & 0,00786 \\
3,0 & 132,888 & 0,33 & 0,00756 \\
3,5 & 140,428 & 0,29 & 0,00712 \\
4,0 & 160,795 & 0,25 & 0,00622 \\
\hline
\end{tabular}

$\mathrm{V}=$ aktivitas enzim $\mu \mathrm{mol}$ 6-APA $/ \mathrm{mL}$ enzim 


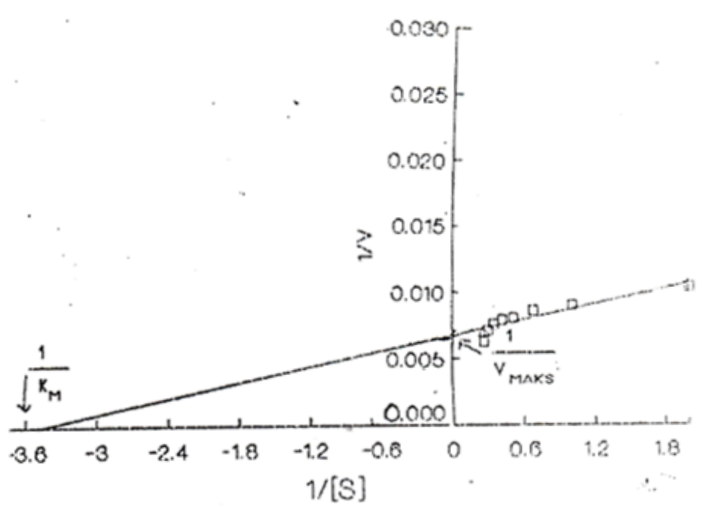

Gambar 3. Hubungan antara $1 / v$ dan $1 /[S]$ dari enzim penisilin asilase.

Dari gambar diperoleh nila $\mathrm{K}_{\mathrm{m}}$ sebesar 0,86 $\mu \mathrm{M}$, sedangkan $\mathrm{V}_{\mathrm{m}} 147,93 \mu \mathrm{mol}$ 6-APA $/ \mathrm{mL}$ enzim

\section{KESIMPULAN}

Dari hasil penelitian dapat disimpulkan bahwa enzim penisilin asilase hasil isolasi dari Eschericia coli B-130 mempunyai $\mathrm{pH}$ optimum 7,5 temperatur optimum $55^{\circ} \mathrm{C}$, tetapan Michaelis Menten $\left(\mathrm{K}_{\mathrm{m}}\right)=0,86 \mu \mathrm{m}$ dan kecepatan reaksi maksimum $\left(\mathrm{V}_{\mathrm{m}}\right)=147 \mu \mathrm{mol}$ 6-APA/mL enzim.

\section{UCAPAN TERIMA KASIH}

Penulis mengucapkan terima kasih yang sebesar-besarnya kepada DR. Muhammad Wirahadikusumah (alm) dan DR. Muliawati Sinduwarta, staf pengajar Kimia FMIPA-ITB atas bantuan dan bimbinganmya.

\section{PUSTAKA}

1. Gillman, G.A, L.S. Goodman., T.W. Rall, and F. Murad. "The Pharmacologi-cal Basis of Therapeutics", $7^{\text {th }}$ ed., Macmillan Publishing Company, New York, 1985, 1115-1137.

2. Crueger, W., and A Crueger, "Biotech-nology A Textbook of Industrial Micro-biology", Science Tech. Inc. Madison USA, 1984, 178180, 197-206.

3. Perlman, D(editor)., "Advances in Apli-ed Microbiology", vol XII, Academic Press, New York, 1974

4. Carington, T.R., ProC. R. SoC. London., 179, $321 \cdot 333$.

5. Huber, F.M. R.R. Chauvette, and. B.G. Jackson, "Chepalosporin \& Penicillius", Academic Press, New York, 1972, 27-37

6. Balashingham, et. al., "The Isolation and Kinetics of Penisillin Amidase from E.E.coli'", Biochemical 1972. 